\title{
COMPARATIVE MOLECULAR STUDIES OF HALOPHILIC BACTERIA FROM SALINE WATER AND SOIL IN THE SAUDI ENVIRONMENT
}

\author{
ESTUDOS MOLECULARES COMPARATIVOS DE BACTÉRIAS HALOFÍLICAS DE \\ ÁGUA SALINA E DO SOLO NO AMBIENTE SAUDITA
}

\author{
Mohamed Morsi M. AHMED ${ }^{1,2, ~}{ }^{*}$; Md. Mohibul Alam KHAN ${ }^{1}$; Saleh M. S. AL-GARNI ${ }^{1}$; \\ Roop Singh BORA ${ }^{1,3}$; Saleh A. KABLI ${ }^{1}$ \\ 1. Department of Biological Sciences, Faculty of Science, King Abdulaziz University, Jeddah 21589, Saudi Arabia; \\ 2. Nucleic Acids Research Department, Genetic Engineering and Biotechnology Research Institute (GEBRI), City for Scientific \\ Research and Technological Applications, Alexandria, Egypt; \\ 3. Department of Biotechnology, College of Agriculture, Eternal University, Baru Sahib-173101, HP, India. \\ * Corresponding author. Mohamed Morsi M. Ahmed, mmmahmed6@yahoo.ca
}

\begin{abstract}
Halophilic bacteria are microorganisms that grow optimally in the presence of the very high concentration of sodium chloride. Halophiles are vital sources of various enzymes including hydrolases, which are very stable and catalytically highly efficient at high salt concentration and other extreme conditions such as high temperature, $\mathrm{pH}$ and presence of organic solvents. Several hydrolases such as amylases, proteases, and lipases have been obtained from halophilic bacteria and are commonly used for various industrial applications. We initiated a screening to isolate and characterize the halophilic bacteria from the Red Sea, which is one of the saltiest bodies of water in the world. Water and soil samples, collected from the Red Sea coast, Jeddah, Saudi Arabia, were screened for isolation of halophilic bacteria. Ten bacterial isolates were obtained, which were characterized by biochemical tests and 16S rRNA gene sequencing. Hydrolase producing bacteria among the isolates were screened by plate assay on starch and gelatin agar plates for amylase and protease, respectively. Two bacterial isolates i.e. Bacillus glycinifermentans S3 and Enterobacter cloacae W1 were found to possess significant amylase and protease activity.
\end{abstract}

KEYWORDS: Halophiles. Salinity. 16S rRNA gene. Hydrolases. Protease. Amylase.

\section{INTRODUCTION}

Halophiles or "salt-loving" are microorganisms that can thrive in very high salt concentrations. Halophiles are important sources of various enzymes that are very stable and catalytically efficient at high salt concentrations and other extreme conditions such as high temperature, $\mathrm{pH}$ and presence of organic solvents. Various hydrolases including amylases, proteases, and lipases have been derived from halophilic microbes and are being used extensively for various biotechnological applications. Recently, several screening projects have been undertaken in saline habitats to isolate new strains of halophilic bacteria producing novel enzymes with unique properties. Kuberan, Sangaralingam, and Arasu (2010) isolated two halophilic bacterial strains, namely Bacillus sp. tk1 and Bacillus sp. tk2 from the salt pan in Tuticorin, Tamilnadu, India and demonstrated their ability to produce protease enzymes. The production of industrially important enzymes was found to be higher in both the strains during the growth in lowcost substrate like green gram husk under solid-state fermentation. The purified protease has various applications in detergent industries, food industries and pharmaceutical industries (AL-SAARI et al., 2015; PIETILÄ et al., 2016). Zaki et al. (1980) isolated two hundred and four bacterial isolates representing rhizospheric halophiles of five salt marsh plants at Shuaiba lagoon in Saudi Arabia. These bacterial isolates were divided into five distinct groups, namely Sporeformers, Gram -ve and Gram +ve non-spore-forming rods, Cocci, and pleomorphic forms. Sporeformers, which were predominant isolates, were subjected to detailed biochemical and taxonomical studies and it was found that this group (108 isolates) showed marked saccharolytic, amylolytic, cellulolytic and proteolytic activities, but lacked pectinolytic and lipolytic abilities. This study suggested that this group of microorganisms is involved in the mineralization processes which are taking place in the rhizosphere of salt marsh plants. In another study, Sankaranarayanan et al. (2014) reported the bacterial diversity of cyanobacterial mats of the Persian G. coast of SA, which experience extremes salinity. The isolates were analyzed by using denaturing gradient Gel Electrophoresis and 16S rRNA gene sequencing. Moreover, their ability to degrade oil compounds at different salinity and temperature i.e., $5-50^{\circ} \mathrm{C}$ was also evaluated. 
Comparative molecular...

Analysis of 16S rRNA gene sequences revealed that $15 \%$ of the sequences obtained are probably from unknown bacteria. The optimum degradation of phenanthrene and dibenzothiophene was observed at $3.5 \%$ salinity. These compounds are also degradable at $8 \%$ salinity. The same compounds have been degraded at temperatures of between 15 and $40^{\circ} \mathrm{C}$, but not at $50^{\circ} \mathrm{C}$. The optimum temperature was found to be 28 to $40^{\circ} \mathrm{C}$ for the degradation of both aliphatic and aromatic compounds. This study indicated that the microbial mats studied from Saudi Arabia are rich in microbes with the ability to degrade oil compounds at very high salinities and temperatures (AL-SAARI et al., 2015; PIETILÄ, 2016).

The current study aimed to isolate, characterize and identify halophilic bacteria from Red Sea water and coastal saline soils, and to screen them for their ability to produce amylase and protease enzymes.

\section{MATERIAL AND METHODS}

\section{Isolation of bacteria}

Soil and water samples were collected from the Red Sea coast, Jeddah, Saudi Arabia $\left(21^{\circ} 16^{\prime} 3^{\prime \prime}\right.$ N, 39 $9^{\circ} 39^{\prime \prime}$ E). Serial dilutions (up to $10^{-4}$ ) of soil and water samples were prepared using sterile distilled water and $100 \mu \mathrm{l}$ aliquots from each dilution were spread on nutrient agar (NA) plates and incubated at $30{ }^{\circ} \mathrm{C}$ for $72 \mathrm{~h}$. Morphologically distinct bacterial colonies were selected for further screening and individual bacterial isolates were preserved in $20 \%$ glycerol solution at $-20{ }^{\circ} \mathrm{C}$. Bacterial strains isolated from soil and water samples were designated as "S (1-5)" and "W (15)", respectively.

\section{Biochemical characterization}

\section{Gram-staining}

Gram- staining was performed according to Cerny (1976).

\section{KOH hydrolysis test}

A rapid method for the differentiation of plant-associated bacteria without Gram-staining (SUSLOW; SCHROTH; ISAKA, 1982) was followed to differentiate the bacterial isolates. Two drops of $3 \% \mathrm{KOH}$ solution were placed on a glass slide. One loopful of bacterial colonies were added to the $\mathrm{KOH}$ solution and mixed thoroughly with a sterile toothpick. Within 10 seconds the bacterial suspension became viscous and on drawing it with a sterile toothpick it formed a fine thread of slime 0.5-

\section{AHMED et al.}

$1 \mathrm{~cm}$ in length. This indicated that the test was positive for $\mathrm{KOH}$ hydrolysis, and the bacterium was Gram-negative.

\section{Oxidase test}

An aqueous solution (1\%) of tetramethyl-pphenylenediamine was used as a test reagent (SHEKHAWAT; CHAKRABARTI; GADEWAR, 1992). A strip of filter paper (Whatman No. 1) was placed on a glass petri dish and soaked with 2 drops of $1 \%$ freshly prepared a tetramethyl-pphenylenediamine solution. A loopful of bacteria from a 24-hour grown culture in the NA medium was rubbed on the impregnated area on the strip using a sterile toothpick. The test is positive if a purple color develops within 10-60 s.

\section{Catalase test}

To test the catalase activity, bacterial cultures were grown in an NA medium for $24 \mathrm{~h}$. A loopful of each bacterial culture was mixed with a drop of $\mathrm{H}_{2} \mathrm{O}_{2}$ on a clean glass slide to observe the production of gas bubbles which indicates a positive reaction for catalase (HAYWARD, 1992).

\section{Ammonia production}

The production of ammonia by bacterial isolates was tested according to Cappuccino and Sherman (1992). Bacterial strains were grown in 5 $\mathrm{mL}$ of peptone broth and incubated at $30^{\circ} \mathrm{C}$. After $72 \mathrm{~h}$ of incubation, $0.5 \mathrm{ml}$ of Nessler's reagent was added to bacterial suspensions. The development of brown to the yellow color indicated ammonia production.

\section{Screening for hydrolase producing bacteria}

Hydrolase producing bacteria among the isolates were screened by plate assay on starch and gelatin agar plates for amylase and protease, respectively according to Kumar et al. (2012). Amylolytic activity of the cultures was screened on nutrient agar plates containing $10 \mathrm{~g}^{-1}$ of starch $(\mathrm{pH}$ 7.0). After incubation at $30{ }^{\circ} \mathrm{C}$ for $72 \mathrm{~h}$, the zone of clearance was determined by flooding the plates with an iodine solution. The proteolytic activity of the isolates was similarly screened on nutrient agar plates containing $10 \mathrm{~g} \mathrm{~L}^{-1}$ of gelatin. The isolates showing zones of gelatin clearance upon treatment with mercuric chloride solution were designated as protease producing bacteria.

\section{Genomic DNA Purification from Bacteria}

DNA was extracted by using QIAamp Genomic DNA Purification kits by following the manufacturer's instructions. 
Comparative molecular...

16S rRNA gene PCR amplification and phylogenetic analysis

16S rDNA was amplified using the following primers: Forward primer: 5'CAGCGGTACCAGAGTTTGATCCTGGCTCAG 3', reverse primer: 5' CTCTCTGCAGTACGGCTACCTTGTTACGACT $\mathrm{T}-3$ '. PCR was set at $94{ }^{\circ} \mathrm{C}$ for $\min 4 \mathrm{~min}$ for denaturation's; 30 cycles and the amplification were carried out at as following, $94{ }^{\circ} \mathrm{C}$ for $1 \mathrm{~min}, 58{ }^{\circ} \mathrm{C}$ for $30 \mathrm{sec}, 72^{\circ} \mathrm{C}$ for $1.5 \mathrm{~min}$, final extension $10 \mathrm{~min}$ and $4{ }^{\circ} \mathrm{f}$ incubation at the end of the last cycle. The amplified gene was resolved with agarose gel electrophoresis and illuminated under UV and used for sequencing. The $16 \mathrm{~S}$ rDNA sequences were then compared with the available sequences at the GenBank of NCBI using BLAST. A phylogenetic
AHMED et al.

tree was constructed using the neighbour-joining method (SAITOU; NEI, 1987) with MEGA 7.0.26 (KUMAR; STECHER; TAMURA, 2016). The evolutionary distances were computed using the Kimura 2-parameter model (KIMURA, 1980).

\section{RESULTS AND DISCUSSION}

\section{Isolation and biochemical characterization of halophilic bacteria}

Bacterial isolates $\mathrm{S} 1, \mathrm{~S} 2, \mathrm{~S} 3, \mathrm{~S} 4, \mathrm{~S} 5$, and W2 were found to be Gram-positive (Table 1). These isolates were negative in the $\mathrm{KOH}$ hydrolysis test, as expected. Bacterial isolates W1, W3, W4, and W5 were found to be Gram-negative as confirmed by Gram staining and $\mathrm{KOH}$ hydrolysis test as shown in Table 1.

Table 1. Biochemical characterization of the bacterial isolates

\begin{tabular}{|c|c|c|c|c|c|}
\hline Isolates & Gram stain & $\mathrm{KOH}$ hydrolysis test & Oxidase & Catalase & $\begin{array}{l}\text { Ammonia } \\
\text { production }\end{array}$ \\
\hline S1 & + & - & + & + & + \\
\hline $\mathrm{S} 2$ & + & - & - & + & + \\
\hline S3 & + & - & + & + & - \\
\hline S4 & + & - & + & + & + \\
\hline S5 & + & - & + & + & + \\
\hline W1 & - & + & + & + & + \\
\hline W2 & + & - & + & + & + \\
\hline W3 & - & + & - & + & + \\
\hline W4 & - & + & - & + & - \\
\hline W5 & - & + & - & + & + \\
\hline
\end{tabular}

All the ten bacterial isolates were found to be positive for the Catalase test as the production of gas bubbles was seen after mixing bacterial culture with a drop of $\mathrm{H}_{2} \mathrm{O}_{2}$ (Table1 and Figure1). Bacterial isolates $\mathrm{S} 1, \mathrm{~S} 3, \mathrm{~S} 4, \mathrm{~S} 5, \mathrm{~W} 1$, and $\mathrm{W} 2$ were positive for the Oxidase test as the addition of bacterial culture on filter paper soaked with tetramethyl-p-

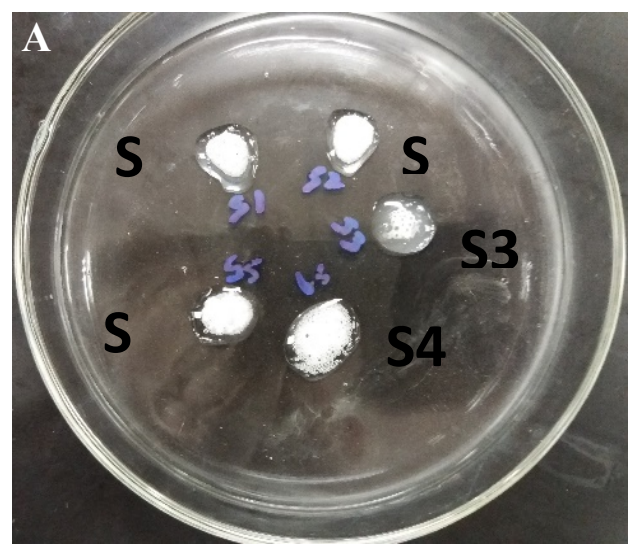

phenylenediamine solution, resulted in the development of purple color (Table 1 and Figure2). In the case of bacterial isolate $\mathrm{S} 2, \mathrm{~W} 3, \mathrm{~W} 4$, and $\mathrm{W} 5$, no purple color were detected within 10-60 s, hence these isolates were negative for the oxidase test (Figure2).

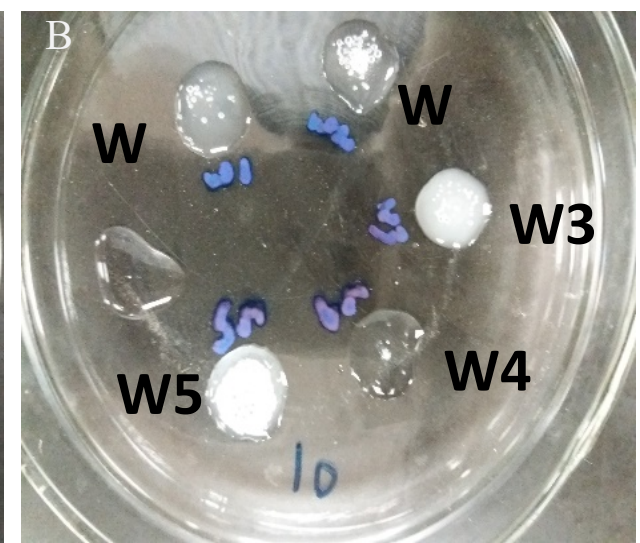

Figure 1. Catalase test. (A) Soil samples S1 -S5 (B) Seawater samples W1-W5. 

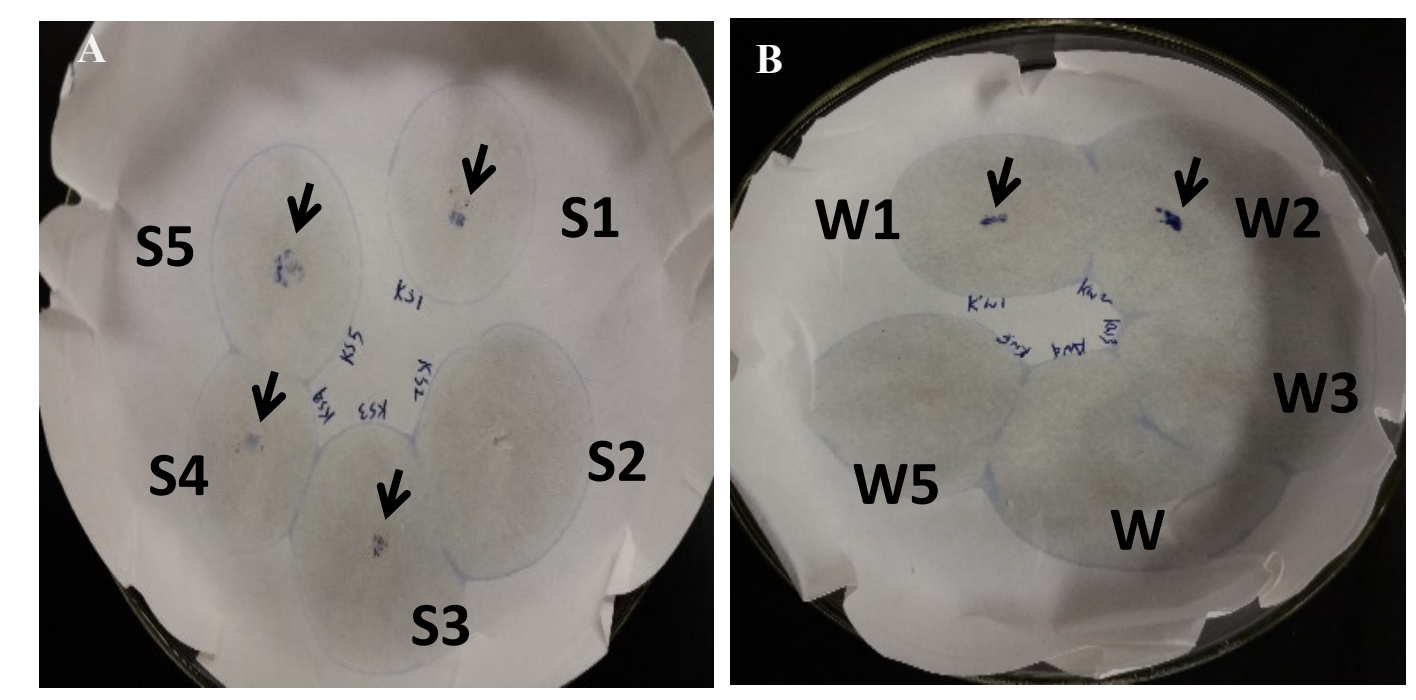

Figure 2. Oxidase test. (A) Soil Samples (S1-S5) and Red sea Water samples (W1-W5). The development of purple color is indicated by arrows.

To determine the production of ammonia, Nessler's reagent was added to the bacterial suspension, grown for 3 days. The development of brown color confirmed the ammonia production. As seen in Figure 3, the development of brown color

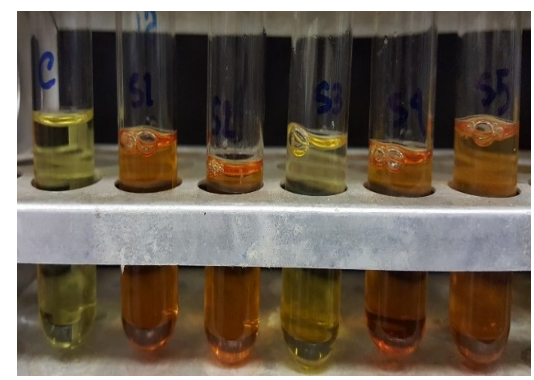

\section{$\begin{array}{llllll}C & \text { S1 } & \text { S2 } & \text { S3 } & \text { S4 } & \text { S5 }\end{array}$}

Figure 3. Production of Ammonia by bacterial isolates.

\section{Identification of bacterial strains using $16 \mathrm{~S}$ rRNA gene sequence analysis}

Genomic DNA was isolated from the bacterial strains, isolated from Red seawater and soil. The $16 \mathrm{~S}$ rDNA gene was amplified using the Universal Primer set and DNA sequencing was carried out. The DNA sequence was searched against the GenBank database (www.ncbi.nlm.com) using the BLAST tool. Nucleotide sequence alignment of $16 \mathrm{~S}$ rDNA genes and subsequent phylogenetic analysis revealed the identity of the halophilic bacterial strains isolated from red seawater and soil as mentioned in Figure4 and Table 2.

Accession numbers are provided in the parentheses following the binomial name of each was detected in isolate $\mathrm{S} 1, \mathrm{~S} 2, \mathrm{~S} 4, \mathrm{~S} 5, \mathrm{~W} 1, \mathrm{~W} 2, \mathrm{~W} 3$, and W5, indicating the ammonia production. However, in the case of isolates, S3 and W4, there was no development of brown color (Figure3, Table $1)$.

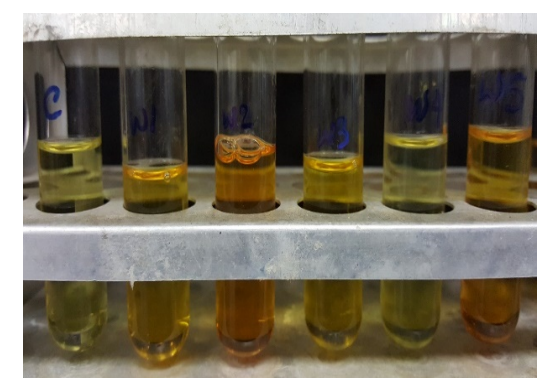

\section{W1 W2 W3 W4}

isolate. The significance of each branch is shown by a bootstrap value based on 1000 replications.

\section{Screening for hydrolase producing bacteria}

Hydrolase producing bacteria among the isolates were screened by plate assay on starch and gelatin agar plates for amylase and protease, respectively. Amylolytic activity of the cultures was screened on nutrient agar plates containing starch. The zone of clearance was determined by flooding the plates with an iodine solution. Only three bacterial isolates i.e. Bacillus glycinifermentans(S3), Bacillus badius(S5) and Enterobacter cloacae (W1) exhibited significant amylase activity (Figure5 and Table 2). 


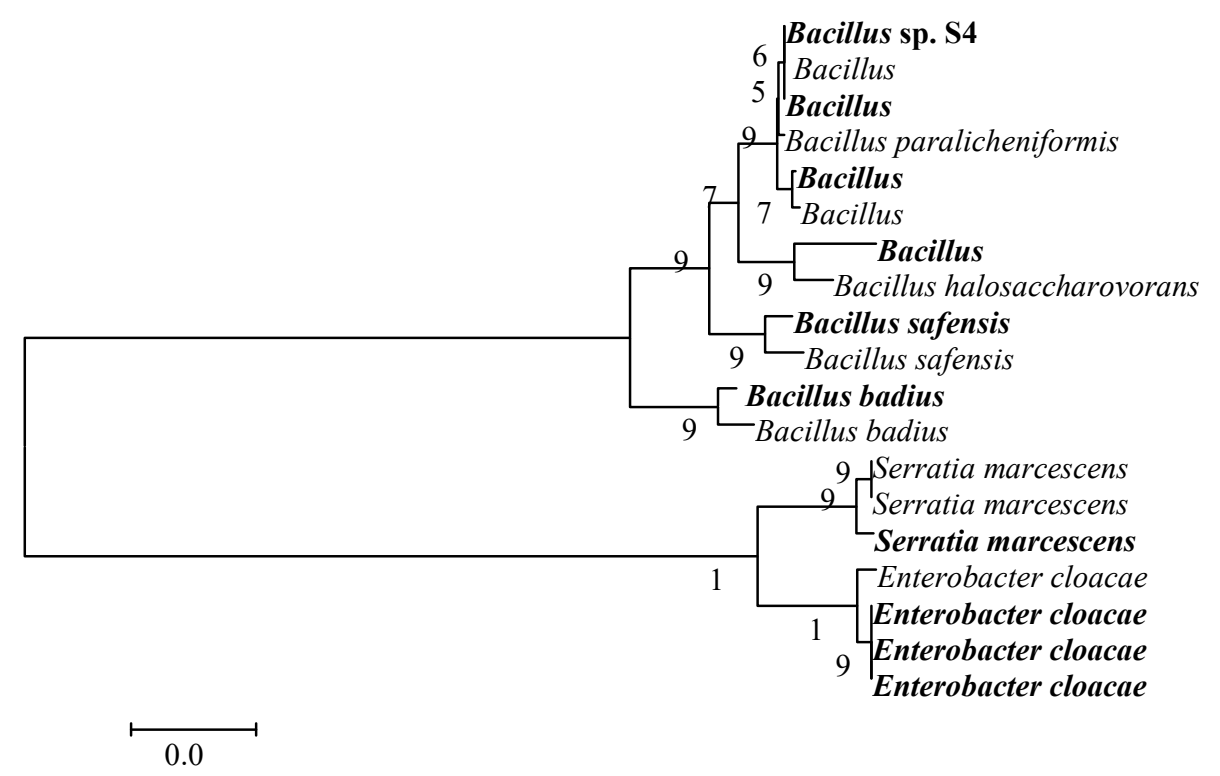

Figure 4. Phylogenetic tree displaying the position of the isolated bacterial strains to closely related bacteria.

Table 2. Amylolytic and proteolytic activities of the isolated bacterial strains

\begin{tabular}{llllll}
\hline Isolates & Accession no. & $\begin{array}{l}\text { Closest species from } \\
\text { NCBI (Blast) }\end{array}$ & $\begin{array}{l}\text { 16S } \\
\text { similarity (\%) }\end{array}$ & $\begin{array}{l}\text { Amylolytic } \\
\text { activity }\end{array}$ & $\begin{array}{l}\text { Proteolytic } \\
\text { activity }\end{array}$ \\
\hline S1 & MK942414 & Bacillus safensis & 99.82 & - & - \\
S2 & MK942415 & Bacillus paralicheniformis & 100 & - & - \\
S3 & MK942416 & Bacillus glycinifermentans & 100 & + & + \\
S4 & MK942417 & Bacillus sp. & 99.91 & - & + \\
S5 & MN589650 & Bacillus badius & 100 & + & + \\
W1 & MK942425 & Enterobacter cloacae & 99.73 & + & + \\
W2 & MK942426 & Bacillus & 99.25 & - & - \\
W3 & MK942427 & Serratia marcescens & 100 & & - \\
W4 & MK942428 & Enterobacter cloacae & 100 & - & - \\
W5 & MK942429 & Enterobacter cloacae & 100 & - & - \\
\hline
\end{tabular}

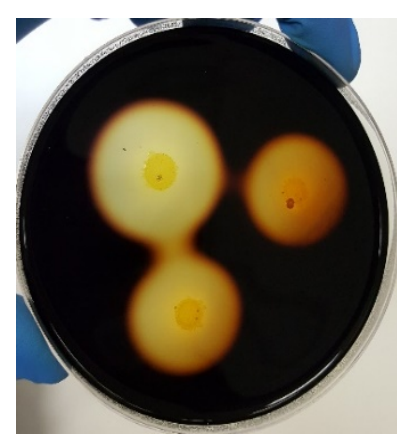

S3

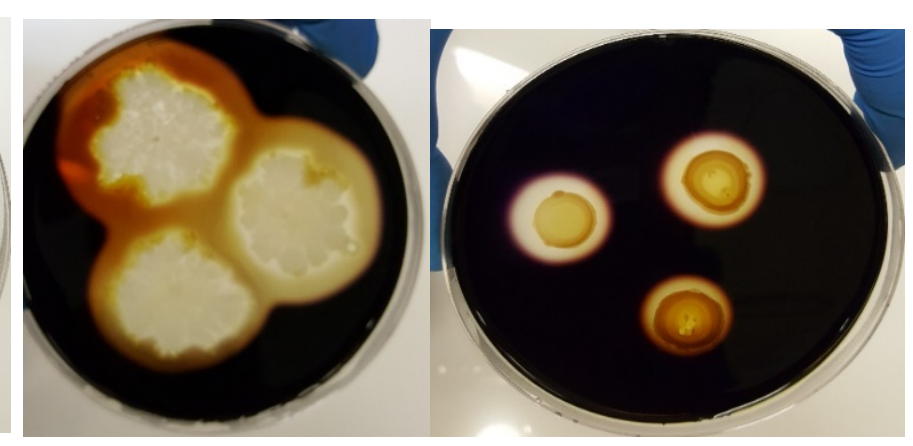

S5
W1

Figure 5. Screening of bacterial isolate for Amylase activity

The proteolytic activity of the bacterial isolates was screened on nutrient agar plates containing gelatin. The isolates showing zones of gelatin clearance upon treatment with mercuric chloride solution were designated as protease producing bacteria. Among the ten bacterial isolates tested for proteolytic activity, only three strains i.e bacterial isolate Bacillus 


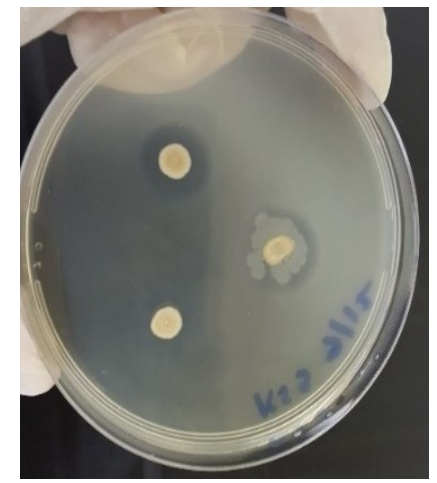

S3

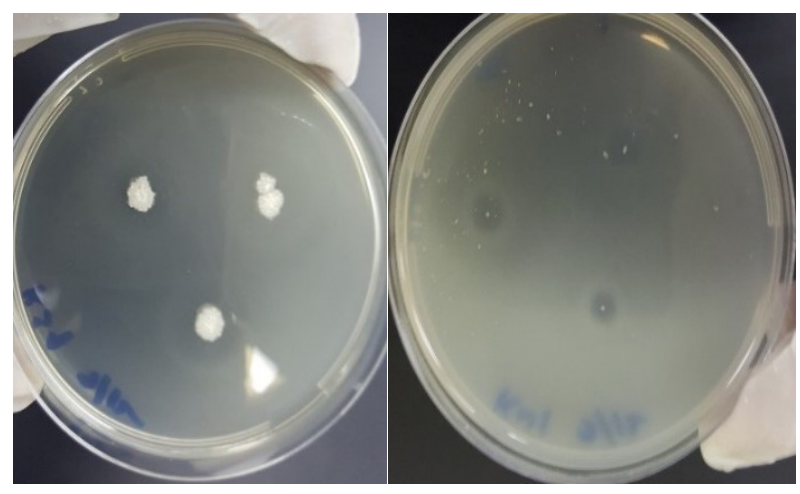

S4
W1

Figure 6. Screening of bacterial isolate for Protease activity.

The existence of a large region of saline water around the earth's surface has provided suitable conditions for the emergence and evolution of halophiles or salt-loving organisms. Halophiles have evolved different strategies to survive in the presence of very high salt concentrations. The halophilic bacteria accumulate $\mathrm{K}^{+}$ions in the cytoplasm to balance the osmotic pressure induced by high salt concentration in the surrounding environment (MADIGAN; OREN, 1999; OREN, 2002). Besides, halophiles accumulate osmoprotectants in the cytoplasm which provide osmotic balance and thus allow the normal functioning of a cell even at a very high salt concentration (NIETO; VARGAS, 2002). Enzymes derived from halophilic bacteria are very stable and active at very high salt concentration and hence have tremendous potential in various biotechnological applications including biosynthetic processes, environmental bioremediation, and food processing. Besides, high activity in the presence of high salt concentrations, these enzymes are also catalytically very active at high temperatures and in the presence of organic solvents. Several screening projects have been undertaken in saline habitats to isolate new strains of halophilic bacteria producing novel enzymes with unique properties. Halophilic microbes have been mainly isolated from hypersaline lakes, the Dead Sea, saltern crystallized ponds, and solar lakes. We have isolated the halophilic microorganisms from the Red seawater and soil. The Red Sea is one of the saltiest bodies of water in the world due to the very high rate of evaporation. The salinity of the Red Sea ranges from $36 \%$ in the southern region and $41 \%$ in the northern region. We screened soil and water samples from the Red Sea and obtained 10 bacterial isolates. These strains were further screened for the production of hydrolases. Two bacterial isolates i.e. Bacillus glycinifermentans S3and Enterobacter cloacae W1were found to possess significant amylase and protease activity.

\section{CONCLUSIONS}

We have isolated and characterized halophilic bacteria from the Red sea which is one of the saltiest bodies of water in the world due to the very high rate of evaporation.

Two bacterial isolates i.e. Bacillus glycinifermentans S3and Enterobacter cloacae W1exhibited significant amylase and protease activity.

\section{ACKNOWLEDGMENT}

This project was funded by the Deanship of Scientific Research (DSR) at King Abdulaziz University, under grant no. G: 80-130-1439 The authors, therefore, acknowledge with thanks DSR for technical and financial support.

RESUMO: Bactérias halofílicas são microrganismos que crescem de maneira ideal na presença de uma concentração muito alta de cloreto de sódio. Halófilos são fontes vitais de várias enzimas, incluindo hidrolases, que são muito estáveis e cataliticamente altamente eficientes em alta concentração de sal e outras condições extremas, como alta temperatura, $\mathrm{pH}$ e presença de solventes orgânicos. Várias hidrolases como amilases, 
proteases e lipases foram obtidas a partir de bactérias halofílicas e são comumente usadas para várias aplicações industriais. Iniciamos uma triagem para isolar e caracterizar as bactérias halofílicas do Mar Vermelho, que é um dos corpos de água mais salgados do mundo. Amostras de água e solo, coletadas na costa do Mar Vermelho, Jeddah, na Arábia Saudita, foram examinadas quanto ao isolamento de bactérias halofílicas. Foram obtidos dez isolados bacterianos, caracterizados por testes bioquímicos e seqüenciamento do gene 16S rRNA. As bactérias produtoras de hidrolase entre os isolados foram triadas por ensaio em placa em placas de amido e ágar de gelatina para amilase e protease, respectivamente. Verificou-se que dois isolados bacterianos, isto é, Bacillus glycinifermentans S3 e Enterobacter cloacae W1, possuíam significativa atividade de amilase e protease.

PALAVRAS-CHAVE: Halófilos. Salinidade. Gene do rRNA 16S. Hidrolases. Protease. Amilase.

\section{REFERENCES}

AL-SAARI, N.;GAO, F.;ROHUL, A. A.; SATO, K.; SATO, K.; MINO, S.; SUDA, W.; OSHIMA, K.; HATTORI, M.; OHKUMA, M.; MEIRELLES, P. M.; THOMPSON, F. L.; THOMPSON, C.; FILHO, G. M.; GOMEZ-GIL, B.; SAWABE, T.; SAWABE, T. Advanced Microbial Taxonomy Combined with GenomeBased-Approaches Reveals that Vibrio astriarenae sp. nov., an Agarolytic Marine Bacterium, Forms a New Clade in Vibrionaceae. 2015 Aug 27;10(8): e0136279. https://doi.org/10.1371/journal.pone.0136279

CAPPUCCINO, J. C.; SHERMAN, N. Microbiology: a laboratory manual. Benjamin/Cummings, New York, USA, 1992.

HAYWARD, A. C. Identification of Pseudomonas solanacearum. In: SAVERNET bacterial wilt training course held from October 5 to November 16 AVRDC. pp 101, 1992.

KIMURA, M. A simple method for estimating evolutionary rates of base substitutions through comparative studies of nucleotide sequences. J. Mol. Evol. 16:111-120, 1980. https://doi.org/10.1007/BF01731581

KUBERAN, T.; SANGARALINGAM, S.; ARASU, V. T. Isolation, and optimization of Protease producing Bacteria from Halophilic soil. J. B io s c i. Res.,1:163-174, 2010.

KUMAR, S.; KARAN, R.; KAPOOR, S.; SINGH, S. P.; KHARE, S. K. Screening and isolation of halophilic bacteria producing industrially important enzymes. Brazilian Journal of Microbiology, 43:1595-1603, 2012. https://doi.org/10.1590/S1517-83822012000400044

KUMAR, S., STECHER, G.; TAMURA, K. MEGA7: molecular evolutionary genetics analysis version 7.0 for bigger datasets. Mol. Biol. Evol. 33:1870-1874, 2016. https://doi.org/10.1093/molbev/msw054

MADIGAN, M. T.; OREN, A. Thermophilic, and halophilic extremophiles. Curr. Opin. Microbiol. 1999, 2, 265-269. https://doi.org/10.1016/S1369-5274(99)80046-0

NIETO, J. J.; VARGAS, C. Synthesis of osmoprotectants by moderately halophilic bacteria: Genetic and applied aspects. Recent. Res. Devel. Microbiol. 2002, 6, 403-418.

OREN, A. Diversity of halophilic microorganisms: Environments, phylogeny, physiology, and applications. $J$. Ind. Microbiol. Biotechnol. 2002, 28, 58-63. Life 2013, 3 48. https://doi.org/10.1038/sj/jim/7000176

PIETILÄ, M. K.; ROINE, E.; SENCILO, A.; BAMFORD, D. H.; OKSANEN, H. M. Pleolipoviridae, a newly proposed family comprising archaeal pleomorphic viruses with single-stranded or doublestranded DNA, genomes. Vol 161(1):249-56, 2016. https://doi.org/10.1007/s00705-015-2613-x

SAITOU, N.; NEI, M. The neighbor-joining method: a new method for reconstructing phylogenetic trees. Mol. Biol. Evol. 4:406-425, 1987. 
SANKARANARAYANAN, K.; LOWENSTEIN, T. K,; TIMOFEEFF, M. N.; SCHUBERT, B. A.; LUM, J. K. Characterization of ancient DNA supports the long-term survival of Haloarchaea. Astrobiology. 14(7):553-60, 2014. https://doi.org/10.1089/ast.2014.1173

SHEKHAWAT, G. S.; CHAKRABARTI, S. K.; GADEWAR, A. V. Potato bacterial wilt in India (Indian Council of Agricultural Research). Technical Bull 38:16-39, 1992.

SUSLOW, T. V.; SCHROTH, M. N.; ISAKA, M. Application of a rapid method for gram differentiation of plant pathogenic and saprophytic bacteria without staining. Phytopathology, 72:917-918, 1982.

https://doi.org/10.1094/Phyto-72-917

ZAKI, M. M.; HAMED, A.S.; SEJINY, M.J.; BAESHIN, N.A. Activities and taxonomy of Halophilic spore formers in salt marsh plant rhizospheres. Bull. Fac. Sci. K A U, Jeddah, 4:101-107, 1980. 